\title{
Continues Improvement in the Project-based Learning Method to Meet the Ever-Growing Industrial Needs: A Case Study
}

\author{
Thanikachalam Vedhathiri \\ Former Professor and HOD, Center for International Affairs, National Institute of \\ Technical Teachers Training and Research, Chennai, India \\ vthani2025@gmail.com
}

\begin{abstract}
Human capital development in engineering education is continuously based on a projectbased learning approach. For sustainability, it is learned that there is an urgent need for periodical improvements in the project-based curriculum and instructional design and delivery methods to meet the fast-growing technologies. After completion of the projects, most of the administrators assume that the curricula and instructional design need not be periodically evaluated. During and after completion of the project, many evaluations have to be carried out to ensure a better outcome in the planned attributes of the graduates due to project-based learning. This case study demonstrates this concept. During and after completion of the World Bank assisted projects in technician education I-III (1992-2007) in India, a series of evaluative research projects were undertaken to assess the status of planned project-based learning, the utility of resources, and the competencies of the faculty members. The steps to be taken to accelerate the periodic revision of curriculum as and when disruptive technology gains importance. Current needs analyses for planning advanced training programs for the working professionals have been identified based on the results of tracer studies. The outcome of the existing programs indicates the supplying needed industryrelevant human resources and the return on the investments made. Periodical follow-up actions were planned based on the fast changes in the technology applications in various companies. It is concluded that frequent evaluation of project outcomes is essential in sustaining project-based learning. Many new courses are being introduced and many new programs have been developed. The periodical evaluation alone can ensure the sustainability of the project-based curriculum and instructional planning and design.
\end{abstract}

Keywords: Project-based action research studies, Continuous technology evaluation, Space and human resources utilization, Periodical improvements in continuing education, Frequent tracer studies, Periodical impact studies, Continuous check on IRG

\section{Introduction}

Capacity development, quality improvement, and efficiency improvement are based on the economic needs of a state and its institutions. If there is a need for 50 polytechnics in a state, around 267 million US Dollars will have to be earmarked for the project. The polytechnics have to be established near industrial corridors and hubs. There is a need for flawless project planning, the layout of institute buildings, hostels, quarters, roads, workshops, and equipment.

Article history:

Received (August 17, 2021), Review Result (October 2, 2021), Accepted (November 9, 2021) 
The new programs are to be developed to meet the requirements of the companies in the industrial corridor. There is a need for recruiting talented, qualified, and motivated faculty members. The faculty members have to be trained to meet the skills, competencies, and attributes desired by the employers. Further, there is a need for training the technical support staff. In this process, the states are to check the performance of the faculty and students against the planning assumptions. This research paper centers around the research works needed to check the total performance of the faculty and students.

Ministry of Human Resource Development, Government of India has obtained needed loan from the World Bank to improve the Capacity, Quality, and Efficiency of Engineering Education of the polytechnic colleges in India through three different projects. Additional development areas had been funded through savings. The needed human resources had been added through the project. Considering the fast growth of the economy, there is a need for planning more polytechnics in many fast-developing regions. Most of the educational administrators have believed that the fixed project-based curriculum will be good enough for many years but the half-life is less than three years. The skill needs of the graduates are to be continuously updated to meet the fast-changing disruptive technologies. This research explores further.

\subsection{Context to the growth of the economy}

The Look East Policy has been planned by the Government of India to utilize the resources and establish various industries in the North-Eastern States and connect them to the eastern countries. Many industrial corridors are being established in various states. The needed human resources are to be planned not only through the World Bank assisted projects but also through national planning. The states have very good raw materials, mineral resources, forest wealth, and ready market for the finished goods but the available industry-ready human resources are limited. New foreign direct investments bring disruptive technologies. Hence, detailed evaluation studies have been undertaken to identify the adequacy of technician programs to match the fast-growing industrial needs. The curricula have to be project-based so that the graduates can acquire needed industry-relevant attributes. The project-based curriculum and the instructional design are to be fine-tuned based on the fast-growing and disruptive technologies.

\subsection{Purpose of the research}

The data on the implementation of various components of the project had to be collected through the participants like CEOs, Government officials, other consultants, faculty members, students, alumni, employers, entrepreneurs, and society at large. The Research Reports have to be free from errors and should represent the actual state of affairs. These reports have to be placed before the Joint Review Mission (JRM) of the Government Secretaries and the World Bank Officials. If certain components were not implemented as per the approved project implementation plan, then the causes had to be studied and remedial measures are to be taken. Remedial measures are to be undertaken periodically. Such rigorous studies have to be followed even after the completion of the World Bank project. Project-based learning will be successful only when the needs of various fast-growing projects are continuously considered. It is not a one-time project work for developing static project-based curricula and instructional design. 


\section{Literature survey}

The World Federation of Engineering Organizations is mounting major efforts at technical capacity building in developing countries. Economic development for developing countries can be effectively stimulated by building the technical capacity of their workforce. A technical workforce base can then provide several paths to economic development: attraction of technically oriented multi-national companies, who can invest effectively in the developing country once there is a cadre of qualified local employees available; effective utilization of foreign funds, and small business start-ups by technically competent entrepreneurs. Japan after the world war borrowed huge loans from the World Bank and re-established technical education and improved the economy [1][2].

The International Network for Women Engineers and Scientists (INWES) and the World Federation of Engineering Organization (WFEO) are committed to attracting girls to undertake careers in STEM and play an important role in developing and supporting programs that encourage girls to study the enabling subjects of science and mathematics. G7 prepared to guide principles for capacity building of women and girls to contribute to the sustainable development goals [4].

Claire Millington considered the use of tracer studies for enhancing relevance and marketability in online and distance education. Ashenafi Abate Woya (2019) concluded that employability among statistics graduates is due to graduates' attributes, competence, and quality of education. Quality improvement focuses on these. International Labour Organization developed guidelines for conducting tracer studies. According to INTRAC data is collected for monitoring and evaluation purposes. Further, tracer studies are designed to track changes at an individual level, following a development intervention. Continuing Educations programs can be well organized using the modern facilities acquired under the project. The faculty members have been trained to plan, develop, and offer suitable lifelong education courses which create industry-institute interactions. Almost all community colleges, well-established universities in the USA, UK, and Canada plan excellent continuing education programs. According to 'the Evolllution', running a successful continuing education unit requires a great deal of institutional support and a common understanding of the unit's goals and mission. The University of California Leangles offers continuing education programs to the needs of working adults and lifelong learners, with open enrolment and evening, weekend, daytime, and online courses.

Camey [18] evaluated the impact of a community gardening project and concluded that a community gardening program can reduce food insecurity, improve dietary intake and strengthen family relationships. Mteki et al. [17] studied social impacts induced by a development project in Tanzania. IFAD's project-level impact assessment follows a standardized management system implemented with project teams and stakeholders. Standardization ensures comparability across projects along the entire impact assessment cycle. Continuing Education Programs have been introduced in the project. According to World Bank economic rate returns from the project, institutions are to be calculated to augment the debt return [5].

Project-based learning models don't incorporate the evaluation of achievements or shortcomings of engineering education projects. In megaprojects, the whole project is based on the needs assessment of the employers, resources, students' career needs, and future state needs [14][15][18]. Hence, the whole project has to be evaluated for completeness, desired outcome, services, return on investments, and complete satisfaction of the people. Hezmi, [14] evaluated the student abilities, teamwork, and outcomes to meet the surveying standards 
in civil engineering. Hiranyachattada, et al. [15] have developed project-based learning for electrical and instrumentation programs. They created an integrated learning model for project-based learning. Reis [19] prepared a guideline for teaching engineering through project-based learning.

\section{Objectives of action research studies in continuous developments in project-based learning}

(1) Assess the adequacy of the skills and competencies gained in the project-based learning through a tracer study.

(2) Assess the progress in offering needed continuing education programs for the employees of various government departments and micro-enterprises in the region.

(3) Check the adequacy of internal revenue generated by the project polytechnics which indicates the adequacy of resources to meet the fast-growing industries.

(4) Assess the fast-changing skills need based on the new Laws and Acts.

(5) Assess the impact of the project on the economy of the country continuously.

\subsection{Population}

The population comprises alumni of engineering and polytechnic colleges who completed their studies during the project period and were employed in various companies and government departments; parents of the alumni, current students of engineering and polytechnic colleges, government engineering employees, public, entrepreneurs, owners of micro, small, and medium enterprises.

\subsection{Sample}

Sample: Random samples have been chosen from the southern, western, and north-eastern states.

\begin{tabular}{|c|c|c|c|c|c|}
\hline Region & Alumni & Parents & $\begin{array}{c}\text { Current } \\
\text { Students }\end{array}$ & Engineers & $\begin{array}{c}\text { Entrepreneurs/ } \\
\text { owners of MSMEs }\end{array}$ \\
\hline Southern Region & 256 & 28 & 356 & 52 & 19 \\
\hline Northeastern Region & 46 & 50 & 152 & 34 & 8 \\
\hline Total & 302 & 78 & 408 & 86 & 27 \\
\hline
\end{tabular}

\subsection{Research methodology}

For assessing the changing needs of the project-based curricula, it is planned to review the objectives of the project curricula, time frame fixed for completion, visit the institutes, and discuss with the CEOs, heads of departments, faculty members, students, consult state project implementing officers, develop questionnaires for collecting data, validate them, meet the target samples of the actors (heads of departments, faculty members, technical staff, and students), facilitators (training departments and NGOs), beneficiaries (alumni, MSME employers, parents, entrepreneurs, and community members), collect feedbacks, opinions, and suggestions. Analyze the feedback, suggestions, prepare a draft report, and discuss with the CEOs and State Projects Officials. Group discussions were conducted in four cities viz. Chennai (Tamil Nadu), Hyderabad (Andhra Pradesh State), Bangalore (Karnataka State), 
Kalamasseri (Kerala State), in the southern region and three places in the three northeastern cities viz. Shillong (Meghalaya State), Agartala (Tripura State), and Aizawl (Mizoram State) with the randomly selected mixed sample.

Focus areas:

(1) Adequacy of resources procured during the project.

(2) Status of curriculum developed during the project.

(3) Status of continuing education programs.

(4) Consultancy projects are undertaken.

(5) Adequacy of trained faculty members.

(6) Modernization of curriculum.

(7) Satisfaction of the project about capacity development, quality improvement, and efficiency improvement.

(8) Industry-Institute- Community-partnership development after completion of the project.

(9) Tracer studies were conducted after 2005, 2010, and 2015.

(10) Maintenance of equipment after the completion of the project.

Table 1. Feedback

\begin{tabular}{|c|c|c|c|}
\hline $\begin{array}{l}\text { Sl. } \\
\text { No. }\end{array}$ & Focused Area & $\begin{array}{l}\text { Feedback from the Southern } \\
\text { Region }\end{array}$ & $\begin{array}{l}\text { Feedback from the Northeastern } \\
\text { Region }\end{array}$ \\
\hline 1 & Adequacy of Resources & $\begin{array}{c}\text { Adequate during the project } \\
\text { period but there was initiative } \\
\text { after } 5 \text { years }\end{array}$ & Excellent at the time of project \\
\hline 2 & Status of Curriculum & Revised during the project & No major revision after the project \\
\hline 3 & $\begin{array}{l}\text { Status of Continuing } \\
\text { Education Programs }\end{array}$ & $\begin{array}{c}\text { Many programs could not be } \\
\text { conducted due to the shortage } \\
\text { of faculty members }\end{array}$ & $\begin{array}{l}\text { A few programs are being } \\
\text { continued for the junior staff }\end{array}$ \\
\hline 4 & $\begin{array}{c}\text { Consultancy Projects } \\
\text { Undertaken }\end{array}$ & $\begin{array}{l}\text { Only a few projects on } \\
\text { testing of materials }\end{array}$ & Only a few projects on testing \\
\hline 5 & $\begin{array}{l}\text { Adequacy of Trained } \\
\text { Faculty members }\end{array}$ & $\begin{array}{l}\text { Senior members retired and } \\
\text { current vacancy is around 40- } \\
50 \%\end{array}$ & $\begin{array}{l}\text { Out of state faculty resigned and } \\
\text { left. Vacancy is in the range of 50- } \\
60 \% \text { Contract faculty are } \\
\text { employed. }\end{array}$ \\
\hline 6 & $\begin{array}{l}\text { Modernization of } \\
\text { Curriculum }\end{array}$ & $\begin{array}{c}\text { No major efforts were taken to } \\
\text { incorporate the current } \\
\text { technologies }\end{array}$ & A few courses are introduced. \\
\hline $7-\mathrm{a}$ & $\begin{array}{c}\text { Satisfaction on Capacity } \\
\text { Development } \\
\end{array}$ & Excellent & Excellent \\
\hline $7-b$ & $\begin{array}{l}\text { Satisfaction on Quality } \\
\text { Improvement }\end{array}$ & Very good & Very good \\
\hline $7-\mathrm{c}$ & $\begin{array}{l}\text { Satisfaction on Efficiency } \\
\text { Improvement }\end{array}$ & Low & Nil \\
\hline 8 & I-I-C-Partnership & Not effective & Ineffective in many branches \\
\hline 9 & $\begin{array}{l}\text { Tracer Studies Conducted } \\
\text { in } 2005,2010, \text { and } 2020\end{array}$ & No tracer studies undertaken & $\begin{array}{l}\text { No tracer study was undertaken } \\
\text { after completion of the project }\end{array}$ \\
\hline 10 & Maintenance of equipment & $\begin{array}{l}\text { Most of the electronic } \\
\text { equipment are obsolete }\end{array}$ & $\begin{array}{l}\text { Most of electrical equipment need } \\
\text { maintenance. }\end{array}$ \\
\hline
\end{tabular}


Inference:

Most of the problems are due to severe shortage of funds. Many north eastern states employed raw graduates from other regions. They left the colleges due to new jobs available in their states. The administrators have not taken steps to modernize the curriculum. The job potential is maximum in the southern region due to fast growth of industries due to globalized economy, growth of middle class, and growth of ancillary manufactures. Government can offer funds for the professional institutes like NITTTR Chennai to undertake focused research on the industrial development and plan industry-specific curricula, faculty development and modernization of the resources.

\subsubsection{Planning to complete various components of the project planning model}

The project-based learning model that consists of "Needs Analysis, Design, Product Development, Formative Evaluation, Improvement, Development of Needed Diploma Programs, Implementation and Marketing, Summative Evaluation" has been used. The follow-up of the summative evaluation was taken up through a series of research methods. The findings were utilized in improving the project-based curricula of the institutes.

The project has been planned based on the administrative approval of the Central and State Governments.

Project Implementation Unit has been established for implementing the project components as follows: Appointment of Academic Consultant [National Institute of Technical Teacher Training and Research (NITTTR)-Chennai], Procurement Consultant, and Building Construction Consultant. Procurement of Resources (Equipment, tools, consumables, spares, operation manuals, etc.) by procurement consultant. Construction of Classroom Buildings, Laboratories, Workshops, Multipurpose Hall, Staff Quarters, Auditorium, Roads, Playgrounds, Sheds, etc. by building consultant. The academic consultant is involved in coordination with other consultants, revising the curriculum, training the faculty, and undertaking all the research projects.

Planning for Project Completion: A tri-party meeting was arranged with the Procurement Consultant, Building Construction Consultant Nodal Officer of NITTTR, and State Projects Implementation Unit (SPIU), and the status of the work was discussed. The shortcomings are identified. Single window clearance is recommended. For procurements of various components, detailed specifications were developed through the faculty members of the Academic Consultant. It is suggested to publish the tenders in many All-India newspapers. For this, the response was very appreciative and all the components, tools, software were procured.

For completing the buildings, assistance was offered to prepare the specifications for the missing parts and new tenders were published in the All-India newspapers. Many contractors participated in the bidding. The projects were allotted by following the World Bank specifications and norms. Finally, the civil works were completed as per the schedule and all the buildings were handed over to the director of the project. All the resources met the needs of the project institutes. In due course, many advancements in industrial productions started coming, the resources and the capacity have to be increased.

Academic Activities Undertaken by NITTTR Chennai: Periodical needs assessment of various departments in the region; 2. Periodical needs analysis of engineering graduates and technicians; 3. Proposal of various industry-specific programs. 4. Curriculum planning for various programs; 4 . Training needs analysis of the faculty members to implement various cutting-edge programs; Getting approval from All India Council for Technician Education 
(AICTE) for the programs; Selection of faculty members, Support staff, and students; and starting the programs; Training the faculty members; Conduct of the examinations, Placement of the graduates, and Undertaking research studies.

\subsubsection{Study on the success of continuing education programs launched in the project polytechnics [18][22]}

Under the project, many training programs were launched. Some of the significant programs are Training in AUTOCAD for the CPWD engineers, Training in Automobile Repairs through a local workshop, and supporting the trainees under Community Development through Polytechnics. These three projects have been fully utilized. Further, short-term courses were planned in computer application and Internet use. New continuing education programs have been planned in various departments.

Courses Based on the Projects under Progress through Action Research [20]: Many building failures have been reported in the newspapers in the last 50 years. Even the framed structures have failed. Hence a course on building failures has been planned and a few universities already introduced this course. In hydraulic machinery labs, maintenance of centrifugal pumps, reciprocating pumps, deep well pumps, and turbine pumps have been introduced. In soil mechanics, the students are encouraged to take soil samples from the project sites for testing and determining the soil strengths, bearing capacity, and settlement. The students have been taken to various sites where pile foundation is in progress and subsoil improvements are undertaken. In similar ways, the students of mechanical engineering are undertaken by various automobile manufacturing companies.

Local Visits to Business Enterprises: Every year the business enterprises conduct exhibitions to market new products. They follow Research-Development-DisseminationAdoption (RDDA) Model. A visit to these exhibitions would reduce the gaps in modern products, utility, cost, and maintenance. Further, it learned from the alumni that none of the colleges encourage a visit to markets to know the range of products, cost, utility, and quality. When the students attempt to undertake cost estimation and value analysis, they are very much handicapped. Spending a day or two in the exhibitions will yield a rich experience.

\subsubsection{Tracer studies on the alumni $[3][7][10][11][22]$}

Two studies have been completed, one before the project and the other after completion of the project. Most of the alumni in civil engineering, electrical engineering, and mechanical engineering were employed in various government departments like Public Works Department, Electricity Board, SMEs, and Micro enterprises. The final year students have been advised to apply for various jobs in the country.

Based on the feedback further action research has been undertaken in various engineering:

(1) The need to introduce a course on Urban Planning for Civil Engineers is based on: The previous curriculum didn't focus on urban planning but the graduates faced many problems in getting approval for the micro layouts in the metropolitan cities. The layout authority is with the metro engineer. The students have to learn about layout rules, get approval from the revenue department with new survey numbers, establish a power of authority, and get approval from the urban land sealing authority. These rules and methodology have been introduced through selected topics.

(2) Planning group housing layout: This area was not included in the earlier curriculum but had to be introduced based on project-based learning. 
(3) Use of digital technology (AUTO CAD, STADDPRO, Modern Survey, etc.) in planning group building layout Project Management using various new technology-based tools, etc. has been added.

(4) Building Technology and Valuation has been introduced as a new program.

(5) Many sections of Civil Engineering have grown very fast due to growth in GDP. Transportation engineering, multimodal transportation, infrastructure development, environmental engineering, environmental impact analysis, urban planning, multi-storey building construction, wastewater treatment plants, etc. are to be added to project-based learning as electives.

(6) There is a need for bifurcating the Civil Engineering Program into four branches (Transportation Engineering, Environmental Engineering, Building Technology, and Construction Management) to meet the fast-growing demand for specialists.

(7) On-the-job training has been introduced to get needed professional skills.

(8) In Computer Science a course on software engineering has been introduced.

(9) In Mechanical Engineering a course on a product analysis, product development, testing, improvement and mass production, maintenance, and scrap management have been introduced.

(10) In the revised mechanical engineering manufacturing technology has been introduced.

(11) Many new courses like Robotics, Modern Welding Technology, CNC Machines, and the Japanese (Kanban) production methods have been introduced.

(12) For Leather Technology students a new course on Foot Wear Technology has been introduced.

(13) For Costume Design students a course on Fashion Technology has been introduced.

(14) A new diploma course on Architectural Assistantship has been introduced in women polytechnics.

(15) A new course on Animation Engineering has been planned and will be introduced.

(16) For the Wood Technology program, the Paper and Pulp Technology course has been introduced.

(17) For all diploma students, a course on Entrepreneurship Development has also been introduced.

All these are based on the current job opportunities. Hence, project-based learning can be termed a dynamic method of improving the curriculum.

\subsubsection{Process of following new projects and the requirements of graduate attributes [22]}

Considering the fast growth of technology, industrial transformation, and the desired skills of the graduates in the cutting-edge technologies, the following tracking system is suggested:

(1) Review the possible placement of graduates in the new companies and develop linkages for on-the-job training of the students. 
(2) Try to plan workshops for developing short-term courses, practical works, and dissertations.

(3) Recruit short-term adjunct faculty members from the companies.

(4) Get the information on the establishment of new companies, technology, product development process, etc. from the State Industrial Development Corporation.

(5) Try to form a consortium of colleges to mutually share the curriculum development in the emerging technologies.

(6) Conduct seminars to assess the technology-based instructions.

(7) Expand the reach of project-based programs.

\subsubsection{Impact study due to the project $[6][21]$}

Impact study would reveal the desired outcome realized due to the project. It is based on feedback from the public, employers, government departments, entrepreneurs, and microenterprises. To get feedback, opinions, and open suggestions for improving the project activities. Questionnaires have been developed and distributed to the sample, explaining the project's components, their utility for the alumni, students, local micro-enterprises, employees of various organizations, and parents. It covered almost all kinds of public. The participants of the study were requested to give feedback, satisfaction, and unmet needs. Further, they have been requested to fill up the questionnaires are return them to the coordinators within two weeks. The feedback has been analyzed and inferences were drawn. Major outcomes are:

(1) Almost all the citizens were satisfied with the establishment of the project polytechnics with modern facilities so that the parents can educate their children.

(2) Almost all the government engineering departments expressed their satisfaction with the modern facilities of the engineering departments which can be utilized by them for testing the materials and products.

(3) Programs that are not required were discontinued.

(4) New programs are also introduced as cooperative education where the companies share their resources and actively participate in developing industry-specific technicians. Many states offer land for establishing new manufacturing plants, tax reduction, and good support for recruiting local students.

\subsubsection{Economic of return on the project investment}

The utility of various modern facilities created by the World Bank assisted project can be measured by the annual return on investments in each department, faculty training, software, library, continuing education center, buildings, hostel facilities, quarters, and extension centers under the Community Development through Polytechnics. The return indicates the level of efficiency improvement in management. Also, it provides the use of knowledge capital gained by the faculty members. Further, it also indicates the growth of the organizations around the project polytechnic. The annual return has increased every year during the project. 


\section{Results}

Action Research projects have been undertaken at mid-project on Curriculum Development, Enrolment of Women Students, Implementation of Learning Resource Development, Faculty Development, Implementation of Autonomy, Placement of Students, Starting the Continuing Education Programs for Working Professions, Infrastructure development, Hostels, Labs, Workshops, Planning for Completion the remaining Components, Tracer Study of the engineering graduates before to project, Project Impact Study, Utilization of Resources and Space, and service rendered to local micro-enterprises.

\section{Conclusions}

(1) This World Bank assisted project enabled women students to enrol in various engineering programs that are offered in the project polytechnics which is the biggest achievement.

(2) The project polytechnics fully utilized the space, resources, and t trained faculty members. The institute is fit to be elevated to an engineering college.

(3) All the faculty members have been trained in the content, pedagogy, curriculum evaluation, design, instructional materials development, measurement, evaluation, continuing education, and use of power points. This assisted them to plan and conduct participative instruction.

(4) Since there are no medium and large industries in the Union Territory of Andaman and Nicobar Islands, the quantum of internal revenue generated is limited. However, the microenterprises used modern resources.

(5) The continuing education programs are planned exclusively for the benefit of technicians and junior engineers of various government departments.

(6) Tracer studies indicate that the graduates are employed in the local government departments. Most of them did not migrate to the mainland for better employment. There is no scope for establishing any large-scale industry in the islands.

(7) The public, government officials, parents, and students are satisfied with the establishment of modern polytechnic in the southern and the north-eastern states. The Academic Consultants have accomplished very well and provided all needed research supports for the projects without depending on the foreign consultants. All projects received "satisfaction" from the World Bank. The participation of women students was the highest and created a new benchmark in the World Bank assisted project. The Look-East policy of industrialization of the North East was supported by providing trained technicians and engineers.

This research study provided outcomes similar to summative evaluation. Hence, it is recommended to adopt an in-depth evaluation in all mega project-based developments. The shortcomings can be identified and the necessary interventions can be made for project completion. Further, an extension can be made based on the growth of the economy. Under this principle, the project polytechnic has been upgraded into a technology institute. 


\section{References}

[1] A. Kolmos and E. De Graff, "Problem-based and project-based learning in engineering education: Merging models," (2015), DOI.10.1017/CB09781139013451

[2] A. Shekar, "Project-based learning in engineering design education: Sharing best practices," 121st ASEE Annual Conference and Exposition, Indianapolis, IN, USA Paper ID \# 10806, (2014)

[3] C. Millington, "The use of tracer studies for enhancing relevance and marketability in online and distance education,” (2014), https://wikieducator/images/e/e1/PID_424.pdf

[4] G7 Guiding Principles for Capacity Building of Women and Girls: Towards Sustainable, Inclusive and Equitable Growth and Peace

[5] H. Santiago, "The economic rate of return of world bank projects," (2012), Helle L., Tynjala, P. and Olkinuora, E. (2006). Project-based Learning in Post-Secondary Education- Theory, Practice, and Rubber Sling Shots. Higher-Education, vol.51, no.2, pp.287-314

[6] IFAD's impact assessment cycle, https://ifad.org/

[7] Inter-American Center for Knowledge Development in Vocational Training. International Labor Organization. Carrying out Tracer Studies. Volume 6

[8] Ip Wai Hung and Albert, C. K. Choi, and Jimmy S. F. Chan, (2003), “An integrated problem-based learning mod, Jacek Uziak. (2016). A Project-based Learning Approach in an Engineering Curriculum. Canadian Journal of Engineering Education, vol.18, no.2

[9] J. M. Coronado, "Student long-term perception of project-based learning in civil engineering education: An 18- year ex-post assessment: Sustainability MDPL. 2021.13.1949, (2021), DOI:10.3390/sul3041949

[10] J. E. MMills and D. Treagust, "Engineering education, is problem-based or project-based learning, (2003)

[11] Kirkwood Center for Lifelong Learning, https://www.kirkwood.edu/programs/continuingeducation/index.html

[12] L. Al-Sharif, "Project-based learning in undergraduate engineering education," (2014) https://www.researchgate.net/publication/275022404_Project_Based_Learning_in_Undergraduate_Engineeri ng_Education

[13] M. Daun, "Project-based learning with examples from industry in university courses: An experience report from an undergraduate requirement engineering course," IEEE 29th International Conference on Software Engineering Education and Training (CSEET), (2016) DOI:10.1109/CSEET.2016.16

[14] M. A. Hezmi, "Implementation of project-based learning for civil engineering students at Universiti Teknologi Malaysia,” (2015), Proceedings of the APSEC\&ACEC 2015

[15] N. Chaijum and T. Hiranyachattada, "Integrated learning and project-based learning for the project of electrical measurement and instrumentations in an electrical engineering course," European Journal of Science and Mathematics Education, vol.8, no.1, pp.6-11, (2020)

[16] N. Simister and M. O'Flynn, "Tracer studies," INTRAC for civil society, https://en.wikipedia.org/wiki/Longitudinal_Study

[17] N. Mteki, T. Murayama, and S. Nishikizawa, "Social impacts induced by a development project in Tanzania: A case of airport expansion," Impact Assessment and Project Appraisal, vol.35, no.4, pp.272-283, (2017), DOI:10.1080/14615517.2017.1322806

[18] P. A. Camey, "Impact of a community gardening on vegetable intake and family relationships: A communitybased participatory research study," Journal of Community Health, vol.37, no.4, pp.874-881, DOI:10.1007/s10900-011-9522-z

[19] R. Reis, “A guideline for teaching engineering through project-based learning," Tomorrow's teaching and learning, tomorrow's professor postings, (2019), https://tomorrowsprofessor.sites.stanford.edu/posting/1774

[20] V. Thanikachalam, "Study of current employment status and job opportunities for polytechnic graduates in existing and proposed disciplines in various states," (2003) 
[21] V. Thanikachalam, "Project impact studies in the North-Eastern states," World Bank Assisted Project-III for the North Eastern States of India, Joint Review Meeting, (2007)

[22] V. Thanikachalam, "Tracer studies on the alumni of Dr. B. R. Ambedkar government polytechnic," Port Blair, Andaman and Nicobar Islands, India. (2007)

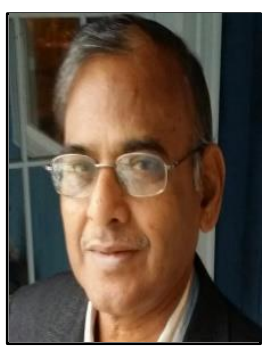

Thanikachalam Vedhathiri

B.E. (1968, Civil Engineering, University of Madras, India), M. Tech. (1970, Indian Institute of Technology, Madras, India), Ph.D. (1975, Filter Design for Earth and Rockfill Dams, University of Madras), M.S., (1988, Instruction System Technology, Indiana University, Bloomington, USA), FIGS., FIE., FFIUCEE, Former Professor, Center for International Affairs, National Institute of Technical Teachers Training and Research, Chennai, India. He was the Senior Researcher under the Fulbright Scheme of the USA and the Nodal Officer for the World Bank assisted projects in Technical Education. 